\title{
Outside the Public Eye: \\ How the Carter Administration Used "Quiet Diplomacy" to \\ Impact Human Rights in Argentina
}

Julia LaBua

From the beginning of his campaign to become President of the United States, Jimmy Carter spoke frequently and forcefully about the role human rights should play in issues of U.S. foreign policy. Carter believed that such policy was a necessary corrective to the overt support given by the Nixon and Ford administrations for right-wing military regimes that routinely violated human rights on the pretext of countering the threat of communist revolution. Support for such abusive regimes, Carter felt, went against the principles upon which the United States had been founded, and had damaged the image of the United States around the world. Carter believed it was possible to maintain vigilance against communist insurgency without condoning human rights abuses, and he found allies in the U.S. Congress, where several pieces of legislation had been passed prior to his election seeking to limit or prevent the U.S. from granting military or economic aid to countries whose governments systematically abused human rights.

Throughout his presidency (1977-1981), Carter never wavered in his public support for a foreign policy that took human rights into account. In numerous speeches, as well as formal and informal news conferences, he reaffirmed his campaign rhetoric calling for the United States to once again live up to the ideals found in its Constitution. Despite Carter's consistent rhetoric, media accounts during his administration reveal a general impression that Carter's devotion to his so-called "human rights crusade" was mere lip service, impractical in the face of geopolitical reality. Carter was forced to defend the apparent contradictions between rhetoric and action in a televised interview with news anchor Barbara Walters. Members of Congress who had been instrumental in passing human rights legislation before Carter took office also publicly criticized how those legislative mandates were implemented. Legislative prohibitions on military aid to countries committing human rights abuses, for example, were so narrowly defined by administration officials as to allow aid shipments to continue.

U.S. government documents declassified in recent years, however, show that at least in one case (Argentina), the relative lack of public condemnation by Carter Administration officials for the military regime's atrocious behavior masked a successful campaign of "quiet diplomacy" being conducted out of the public eye which sought to convince the Argentinean regime to end its human rights abuses. The declassified documents also show that while Carter and some of his 
administrative staff — notably Patricia Derian, Assistant Secretary of State for Human Rights - were committed to incorporating human rights as an element of official foreign policy, they were fighting explicit and implicit messages to the contrary sent to foreign governments about whether the U.S. emphasis on human rights was anything more than political rhetoric. Carter adopted the strategy of quiet diplomacy in an attempt to craft a human rights-centered foreign policy that would satisfy various factions within and outside of the U.S. government. Some members of Congress and the NGO community believed that the human rightsbased foreign policy must be implemented in toto, without exceptions and without regard to national security or other foreign-policy considerations. Other members of Congress and the administration also supported a human rights policy but were primarily interested in wielding it as an anti-communist tool against the Soviet Union and other communist regimes. And still other officials, including many in the Department of Defense and the Central Intelligence Agency, had no patience at all for talk of human rights, believing that the hard-line foreign policy initiated during the Nixon and Ford administrations should be continued. The reduction in numbers of detained political prisoners in Argentina over the course of Carter's time in office shows that contrary to public perception, the strategy of quiet diplomacy had a significant impact on the actions of the military regime in Argentina.

\section{The Origins of Carter's Human Rights Crusade}

In the months leading up to the 1976 presidential election and after he took office, Carter spoke frequently about his vision of crafting a foreign policy based at least in part on encouraging other countries to uphold internationally recognized human rights. In the speech he gave announcing his candidacy in December 1974, Carter expressed a vision of the United States as a country that could once again "set a standard within the community of nations of courage, compassion, integrity, and dedication to basic human rights and freedoms."1 In his January 1977 inaugural address, Carter stated, "Our commitment to human rights must be absolute." speeches he gave to the Organization of American States at the beginning and end of his presidency, Carter spoke of human rights as a value shared by the U.S. and Latin America. "Our own concern for these values will naturally influence our relations with the countries of this hemisphere and throughout the world," he said in 1977..$^{3}$ The message was similar in 1980: "Today no government in this hemisphere can expect silent assent from its neighbors if it tramples the rights of its own citizens."

Carter's human rights rhetoric was undoubtedly a change of pace for the executive branch, but it was not the first initiative within the U.S. government to make human rights a centerpiece of foreign policy decisions. Years before Carter's election, Congress had passed a series of bills aimed at requiring foreign

governments to meet certain human rights standards in order to be eligible for economic or military aid from the United States. One of the earliest was the 1973 
Foreign Assistance Act, drafted by Rep. Donald Fraser (D-Minn.), which called for the president to deny aid to any foreign government that "practices the internment or imprisonment of that country's citizens for political purposes." In 1975, Sen. Tom Harkin (D-Iowa) helped pass an amendment to the International Development and Food Assistance Act that prohibited U.S. aid to any country that consistently violated human rights. Legislation passed in 1976 directed U.S. representatives at the Inter-American Development Bank and the African Development Fund to vote against loans to governments that had engaged in "systematic and gross" violations of human rights. That same year, Congress established a new appointment for Coordinator for Human Rights and Humanitarian Affairs within the State Department (later renamed the Assistant Secretary of State for Human Rights). ${ }^{6}$ During Carter's time in office, Congress passed the Foreign Assistance and Related Programs Appropriations Act of 1978, which specifically prohibited military aid to Argentina on human rights grounds. ${ }^{7}$

A variety of non-governmental organizations also were lobbying during this time for more attention to be paid to human rights. Perhaps the most well known was Amnesty International, founded in 1961, but also active at the time was the Washington Office on Latin America (WOLA), an outgrowth of the National Council of Churches, and the International Commission of Jurists. WOLA, in particular, has been credited with having provided many of the documents and witnesses for the 1973 hearings held by Fraser's Subcommittee on International Organizations and Movements that produced an influential report, "Human Rights in the World Community: A Call for U.S. Leadership." ${ }^{\prime}$ The hearings and report were the basis for Fraser's landmark Foreign Assistance Act. The influence of NGOs went beyond lobbying Congress, however. Amnesty International's publication of country reports detailing human rights abuses and its letter-writing campaigns focused on specific political prisoners, put the issue of human rights abuses before the public, both in the United States and around the world. ${ }^{9}$

\section{Mixed Signals from Within and Without}

Despite Carter's emphatic public statements on the importance of human rights in his foreign policy decisions, members of the media and the public remained skeptical about the extent to which his unquestioned personal commitment translated into active policy. In a television interview with the president and his wife in December 1978, ABC News anchor Barbara Walters asked about the perceived gap between his speeches and his actions: "People said to me, 'You're going to interview the President. Okay, ask him why he doesn't pursue human rights in the Philippines. Ask him why he doesn't do it in Chile. Ask him why he waited so long in Iran." "10 Carter's response to Walters was that governments in those countries and others had in fact felt the pressure from his administration and reacted accordingly, though he offered her national television audience no specific examples. Carter's failure to delineate specific consequences for countries that violated human rights 
likely contributed to public perceptions that the administration's actions did not live up to its stated intentions.

Carter's rhetoric about valuing human rights in foreign policy considerations contrasted sharply with signals sent during the Nixon and Ford administrations, which were mixed at best. A 1976 report written by Robert Hill, then U.S. ambassador to Argentina, about a meeting with Cesar Guzzetti, Foreign Minister of Argentina, states that Guzzetti found Hill's expression of U.S. concern over humanrights violations in Argentina puzzling in light of a recent conversation he had had with U.S. Secretary of State Henry Kissinger in Santiago, Chile. Guzzetti said Kissinger had "hoped the Argentine government could get the terrorist problem under control as quickly as possible." Kissinger's statement was interpreted by Argentina's President Jorge Videla (Guzzetti told Hill) as revealing that the United States" "overriding concern was not human rights but rather that GOA [Government of Argentina] 'get it over quickly'."11 Similarly, a report from Carter's Secretary of State Cyrus Vance offers details of a January 1977 meeting between a State Department officer and Victor Beauge, Political Counselor of Argentina. According to the report, Beauge sought assurances that embassy officials in Buenos Aires were delivering the same message about U.S. commitment to human rights as the State Department. "Beauge persisted, asking if these points had been made by new rpt [repeat] new administration. He said, 'It is essential for your same message to come from all channels. This did not happen in past." 12

There are indications that the mixed messages continued into the Carter Administration. Unpublished notes written by Assistant Secretary Derian in April 1977 after a visit to Argentina reveal that a consistent message on human rights was an elusive goal early in the administration. She warned that the U.S. was sending "a dangerous and double message" to Argentina and other countries. "It is widely believed by our military and intelligence services that the human rights policy emanates only from the Department of State, is a political device and one with a short life due to its wide impracticality, the naiveté and ignorance of individuals in the Administration and to the irresponsible headline-grabbing of members of Congress," she wrote. Derian recommended that Carter send a message to all branches of the military, the CIA, FBI and other intelligence agencies emphasizing the seriousness and permanence of the human rights policy, and that officials who were unable to comply with his directive "be immediately separated from their services." 13 The Argentinean confusion persisted well into the Carter presidency, as illustrated by a report prepared in September 1978 by the Bureau of Intelligence and Research (INR) for Viron P. Vaky, Assistant Secretary for Inter-American Affairs. The Argentinean government, the report stated, believed that "U.S. protests [about human rights] ere largely perfunctory, a temporary outburst of moral fervor reflecting pressure from a few misguided human rights zealots in the Congress and non-governmental organizations." 14 It's not clear from the report whether the confusion was a case of wishful thinking on the part of Argentinean leaders or 
continued mixed messages from various U.S. official entities, but the end result was the same: an apparent lack of clear motivation for the Argentinean regime to reform its rights violations.

The Congress that served alongside Carter was not as ideal an ally in his human rights crusade as it might appear at first glance. While legislative acts such as those listed above attempted to tie foreign aid to respect for human rights, the term "human rights" was not clearly defined in any of them, leaving the granting or denial of aid more or less in the eye of the beholder. ${ }^{15}$ Complicating matters, Congressional supporters of tying aid to human rights abuses had differing agendas: some conservative members of Congress envisioned the legislation being used primarily against the Soviet Union and other leftist or potentially communist regimes; liberal Congressmen placed more emphasis on enforcing the restrictions against totalitarian regimes such as those in Latin America, including Argentina. ${ }^{16}$ This inherent tension within Congress, along with the Carter Administration's insistence on applying the policy framework on a case-by-case basis, meant that no blanket definition of human rights or human rights abuses could be formulated that would apply to all countries. The policy's implementation appeared uneven and seemingly arbitrary to observers - such as the general media - not aware of the painstaking work done by the Interagency Group on Human Rights and Foreign Assistance. This working group, headed by Deputy Secretary of State Warren Christopher, worked throughout the first six months of Carter's presidency to define the administration's human rights policy. ${ }^{17}$

The uneven nature of the policy's application is evident even within a single country such as Argentina. All military aid to Argentina was halted during the Carter Administration, but it was not entirely by U.S. action. Secretary Vance announced a sharp reduction in military aid in February 1977, but it was Argentina itself that refused to accept additional aid as long as human rights conditions were attached. The reduction in aid also only applied to certain categories of military aid, with a rationalization that selling "non-lethal" supplies or existing parts for military weapons and systems was not covered by the ban. Congress, not Carter, implemented a more complete cutoff of military sales and aid to Argentina in October 1978. ${ }^{18}$ Similarly, economic aid to Argentina was reduced, as in the case of the denial of loan credits, but most other economic credits and loans from international financial institutions such as the World Bank were approved despite "no" votes or abstentions by the U.S. representatives - in Argentina's case, this totaled 23 loans between January 1977 and August 1980 -

making the policy's effect more symbolic than concrete. The votes did serve to focus international attention on the U.S. position, however, and could be seen as part of the system of indirect pressure administered by the Carter administration. ${ }^{19}$

\section{The Advent of 'Quiet Diplomacy'}

Even while public sanctions were being attempted with mixed results, 
behind-the-scenes or "quiet" diplomacy continued. During her visit to Argentina in April 1977, Derian delivered to regime officials a private rebuke of their failure to respect the human rights of their political opponents. As detailed in the notes of her visit, Derian was careful not to antagonize the Argentinean leaders. She expressed sympathy for their struggles with terrorists, and reaffirmed the ultimate sovereignty of the regime. Nonetheless, she strongly encouraged the Argentine government to return to internationally recognized standards of law, while refusing to condone the methods used against their opponents: “... Never concede that they are not violating human rights. Impress the serious nature of our concern and the fact that it is here to stay," she wrote in a section of her notes titled "What I Told Them." 20

A similar diplomatic strategy was outlined in a memo written by an unknown State Department staff member in May 1977 for Terence Todman, Assistant Secretary of State for Inter-American Affairs, in advance of a trip to Argentina. The memo offers a series of "talking points" for Todman to use in his meetings with Argentinean officials. Among them: "The impression must be corrected that the Argentinean government is not in full control and must resort to mysterious right wing forces and unexplained disappearances to root out terrorism" and "We strongly urge the acknowledgment of all prisoners under detention, the restoration of due process, and the punishment of all excesses." ${ }^{21}$ Once again, the quiet message being delivered to Argentinean officials is unambiguous: No excuses or rationale will be accepted for the continued violation of opponents' human rights.

These efforts at quiet diplomacy yielded results. An August 1978 memo from Ambassador Castro to Secretary Vance reported, among other things, that "we believe that a number of these reported [interrogation] enters have been closed down as the Argentine security forces have reduced the scale of their anti-subversive operations." ${ }^{22}$ And even as the Barbara Walters interview with Carter was being televised in December of that year, negotiations were ongoing through diplomatic channels between members of Carter's administration and the government of Argentina for a full accounting to be made of detained prisoners, whose numbers had in fact already declined by more than half, from 8,200 in 1974 to 3,400 in 1978.23

Once the efforts of quiet diplomacy began to pay dividends, the tenor changed in the conversation between U.S. and Argentinean officials. A private discussion in September 1979 between Townsend B. Friedman, political officer at the U.S. Embassy in Buenos Aires, and an unnamed "senior member of a major Argentine military intelligence organization" revealed that the attention of Argentinean leaders was beginning to shift from how to continue with or cover up their human rights violations to how to avoid being held accountable for them:

Some of those most deeply involved in the "dirty war" are terribly frightened that as the climate returns to normality they are being moved closer to the time when they must account for their acts and 
suffer retribution. On the other hand, if the "dirty war" can be kept going they are protected ... If the USG [U.S. Government] wanted to do something useful for human rights, he suggested, it would help establish a climate where it would be possible for the GOA to drop a curtain over the past or a curtain that would eliminate the fear that drives the men involved in the dirty war. ${ }^{24}$

The Argentine military official seems to be asking Friedman to promise U.S. support of an amnesty policy to be implemented once the military regime stepped aside. Friedman believed this communication was a concrete indication that Carter's quiet diplomacy was paying dividends. It was a reflection of similar conversations he had had with human rights activists in Argentina, one of them a "foreign correspondent who has been observing Argentina for several years" and a critic of the military regime. "Others in the human rights community are very pleased with our outspokenness," Friedman reports. ${ }^{25}$

The Argentinean government's initial impression of Carter's human rights emphasis as mere rhetoric rather than a serious policy probably played a role in the slowness of its response to U.S. calls to end its rights violations. As early as February 1977, U.S. officials were pressuring the Argentinean regime to publish lists of its thousands of political detainees, to re-establish laws to make future arrests a matter of public record, to allow prisoners to mount a legal defense. ${ }^{26}$ The Argentines did not begin to publish the lists until December of that year, and they were still not complete by March 1978, according to a memo from Raul Castro, U.S. Ambassador to Argentina, which also recommends that the U.S. concentrate further efforts on persuading Argentina to make "continued progress toward return to the rule of law." 27 The failure of Argentinean leaders to comply with an unpublicized agreement with the U.S. to release prisoners, as well as to allow access to prisoners by the Inter-American Commission on Human Rights, was the impetus in August 1978 for the State Department to instruct the Export-Import Bank to withhold more than \$200 million promised for Argentina's Yacyreta dam project. ${ }^{28}$

\section{Conclusion}

Viewing these declassified U.S. government documents in sequence brings the scope, strategy and outcomes of the Carter Administration's human rights-based foreign policy into sharper focus, at least as it was practiced in Argentina. A review of Carter's foreign policy decisions during his presidency reveals unarguable inconsistencies in how the policy was implemented globally, and the uneven effectiveness of public sanctions such as cutting off foreign aid to violators of human rights. But the diplomatic memos and notes show that despite perceptions within the U.S. public, media, and Congress that inconsistencies in the policy rendered it ineffective, there was a steady, unswerving use of quiet diplomacy. What made 


\section{Julia LaBua}

quiet diplomacy so effective was its consistency and persistence. Whether the envoy was Assistant Secretary for Human Rights Patricia Derian, Assistant Secretary for Inter-American Affairs Terence Todman, or U.S. Embassy's political officer Townsend Friedman, the message remained the same: U.S. respect for Argentina's sovereignty coupled with a refusal to accept human rights violations and a belief that regardless of past action, the Argentinean regime was capable of reforming itself and once again implementing the rule of law. This diplomatic effort, combined with occasional public demonstrations that there would be consequences for continued violations - such as the Yacyreta dam project loan rejection - elicited positive if not cataclysmic changes in the scale of human-rights abuses being perpetrated by the military regime of Argentina.

This paper was written for Professor Michel Gobat's Latin America \& the United States: The Historical Perspective. I would like to thank Professor Gobat for his comments and suggestions on the initial drafts of this paper. The paper was named the UI Center for Human Rights' 2007 winner of the undergraduate division of the Burns H. Weston International Human Rights Essay Prize.

\section{Endnotes}

1 Jimmy Carter, "Formal Announcement," in The Presidential Campaign 1976 (Vol. 1). (Washington, D.C.: U.S. Government Printing Office, 1978), 4.

2 Jimmy Carter, "Inaugural Address (January 20, 1977)," in The American Presidency Project [online], ed. John Woolley and Gerhard Peters (Santa Barbara, CA: University of California), $<$ http://www.presidency.ucsb.edu/ws/?pid=6575> (21 October 2006).

3 Jimmy Carter, "Organization of American States Address Before the Permanent Council (April 14, 1977)," in The American Presidency Project [online], ed. John Woolley and Gerhard Peters (Santa Barbara, CA: University of California), <http://www.presidency.ucsb.edu/ws/?pid=7347> (21 October 2006).

4 Jimmy Carter, "Organization of American States Remarks at the 10th Regular Session of the General Assembly (November 19, 1980)," in The American Presidency Project [online], ed. John Woolley and Gerhard Peters (Santa Barbara, CA: University of California) <http://www.presidency. ucsb.edu/ws/?pid=45506> (21 October 2006).

5 William Korey, NGOs and the University Declaration of Human Rights: A Curious Grapevine. (New York: Palgrave , 2001), 184.

6 Ibid., 185.

7 David Carleton and Michael Stohl, "The Foreign Policy of Human Rights: Rhetoric and Reality from Jimmy Carter to Ronald Reagan," Human Rights Quarterly 7, no. 2 (May 1985): 206-207.

8 Korey, 181, 186.

9 David B. Ottaway, "The Growing Lobby for Human Rights," in The Washington Post (Dec. 12, 1976), 31.

10 Jimmy Carter, "Interview with the President and Mrs. Carter: Question and Answer Session with Barbara Walters of the American Broadcasting Company (December 14, 1978)," in The American Presidency Project [online], ed. John Woolley and Gerhard Peters (Santa Barbara, CA: University of California) $<$ http://www.presidency.ucsb.edu/ws/?pid=30303> (21 October 2006).

11 Robert Hill, "Other Aspects of September 17 Conversation with Foreign Minister," in National Security Archive (Washington, D.C.: The George Washington University) <http://www.gwu.edu/ $\sim$ nsarchiv/NSAEBB/NSAEBB73/760920.pdf> (15 October 2006). 


\section{Outside the Public Eye}

12 Department of State, "U.S.-Argentine Relations," in National Security Archive (Washington, D.C.: The George Washington University) <http:/www.gwu.edu/ nsarchiv/NSAEBB/ NSAEBB73/770202.pdf> (19 October 2006).

13 Patricia Derian, "Notes From U.S. Department of State Human Rights Coordinator," in National Security Archive (Washington, D.C.: The George Washington University) < http://www.gwu.edu/ $\sim$ nsarchiv/NSAEBB/NSAEBB85/770405 c memo1.pdf $>$ (15 October 2006).

14 Bureau of Intelligence and Research, "Evolution of U.S. Human Rights Policy in Argentina." In National Security Archive (Washington, D.C.: The George Washington University) < http://www. gwu.edu/ nsarchiv/NSAEBB/NSAEBB73/780911.pdf $>$ (15 October 2006).

15 David F. Schmitz and Vanessa Walker, "Jimmy Carter and the Foreign Policy of Human Rights: The Development of a Post-Cold War Foreign Policy,” Diplomatic History 28, no. 1 (January 2004): 130-31.

16 Hauke Hartmann, “U.S. Human Rights Policy under Carter and Reagan, 1977-1981," Human Rights Quarterly 23 (2001): 413.

17 Schmitz and Walker, 121-26.

18 Cohen, 225.

19 Ibid., 226-27.

20 Patricia Derian, "Notes From U.S. Department of State Human Rights Coordinator."

21 "Human Rights: The Key to Our Relations," in National Security Archive (Washington, D.C.: The George Washington University) < http://www.gwu.edu/ nasarchiv/NSAEBB/NSAEBB85/770504 0000A194.pdf $>$ (15 October 2006).

22 Raul Castro, "Follow Up to Human Rights Roundup," in National Security Archive (Washington, D.C.: The George Washington University) <http://www.gwu.edu/ nsarchiv/NSAEBB/ NSAEBB85/770504 0000A194.pdf> (15 October 2006).

23 Roberta Cohen, "Human Rights Diplomacy: The Carter Administration and the Southern Cone," in Human Rights Quarterly 4, no. 2 (Summer 1982), 234.

24 Townsend B. Friedman, "Human Rights: A Military View," in National Security Archive (Washington, D.C.: The George Washington University) < http://www.gwu.edu/ nsarchiv/NSAEBB/ NSAEBB85/790911 0000A9FB.pdf> (15 October 2006).

25 Ibid.

26 Department of State, "U.S.-Argentine Relations."

27 Raul Castro, "The Problem of Those Who Disappeared," National Security Archive (Washington, D.C.: The George Washington University) < http://www.gwu.edu/ nsarchiv/NSAEBB/NSAEBB85/ index.htm $>$ (15 October 2006).

28 Subcommittee on Inter-American Affairs to the Committee on Internal Relations, "Testimony of Assistant Secretary Derian," in National Security Archive (Washington, D.C.: The George Washington University) <http://www.gwu.edu/ nsarchiv/NSAEBB/NSAEBB85/ 780809 0000A70F.pdf> (15 October 2006).

Julia LaBua is a senior majoring in history and geography. She will graduate in May 2007, and plans to pursue graduate studies in history, with an emphasis on the history of human rights. 